\title{
Konseling Kelompok dengan Terapi Realita dalam Menurunkan Prokrastinasi Akademik
}

\author{
Neneng Suryani Putri \\ UIN Sunan Kalijaga Yogyakarta \\ Email Address: Nenengsuryaniputri@gmal.com
}

Submitted: 2019-03-17, Revised: 2019-03-17, Accepted: 2019-06-25

\begin{abstract}
This study aims to determine whether there is influence group counseling based on reality therapy to the level of student procrastination. Subjects in this study were MA MAFAZA amounting to 14 students. 7 people as experimental group and 7 people as control group. The data collection tools used in this research are: procrastination scale. Data analysis used is Wilxoccon Test which is a statistical method used to test the difference of 2 pieces of data in pairs that is between the control group and the experimental group. The results of analysis using SPSS through Wilxocon Test showed there were 6 samples whose academic procrastination rate was smaller after being treated compared to before. In the positive ranks column showed that no sample whose anxiety level increased after given treatment. While in the Ties column there is 1 sample showing that no change or decrease whatsoever after given treatment. The output shows that the value of $P$ or $P v$ is 0.027 . While the level of significant $(\alpha)$ research of 0.05 . So the value of $P<\alpha$ or $0.027<0.05$ then Ho is rejected, it means there is influence of Group Counseling using Reality Therapy on the decrease of student academic procrastination.
\end{abstract}

Keywords: Group Counseling; Reality Therapy; Academic Procrastination

\begin{abstract}
Abstrak: Penelitian ini bertujuan untuk mengetahui ada tidaknya pengaruh konseling kelompok berdasarkan terapi realitas terhadap tingkat prokrastinasi siswa. Subjek pada penelitian ini adalah siswa MA Mafaza yang berjumlah 14 siswa. 7 orang sebagai kelompok eksperimen dan 7 orang sebagai kelompok kontrol. Alat pengumpulan data yang digunakan dalam penelitian ini adalah: skala prokrastinasi. Analisis data yang digunakan adalah Uji Wilxoccon adalah metode statistika yang biasa dipergunakan untuk menguji perbedaan 2 data yang berpasangan yaitu antara kelompok kontrol dan kelompok eksperimen. Hasil analisis menggunakan SPSS melalui Uji Wilxocon menunjukkan terdapat 6 sampel yang tingkat prokrastinasi akademiknya lebih kecil setelah diberi perlakuan dibandingkan sebelumnya. Pada kolom positive ranks menunjukkan bahwa tidak ada sampel yang tingkat kecemasannya meningkat setelah diberi diberikan perlakuan. Sedangkan pada kolom Ties terdapat 1 sample yang menunjukkan bahwa tidak terjadi perubahan atau penurunan apapun setelah diberi perlakuan. Hasil output menunjukkan bahwa nilai $P$ atau $P v$ sebesar 0,027. Sedangkan taraf signifikan $(\alpha)$ penelitian sebesar 0,05 . Sehingga nilai $\mathrm{P}<\alpha$ atau $0.027<0,05$ maka Ho ditolak, artinya terdapat pengaruh pemberian Konseling Kelompok menggunakan Terapi realita terhadap penurunan tingkan prokrastinasi akademik siswa.
\end{abstract}

Kata Kunci : Konseling Kelompok; Terapi realita; Prokrastinasi Akademik

\section{Pendahuluan}

Salah satu masalah remaja yang kebanyakan dibesarkan oleh guru dan konselor adalah penundaan mereka terhadap tugas-tugas yang telah diberikan oleh guru dan juga kurangnya pengaturan dalam menggunakan waktu. Sehingga waktu hanya terbuang sia-sia tanpa adanya kegiatan yang jelas. Apalagi di era sekarang ini yang kebanyakan remaja lebih senang berinteraksi dengan dunia gadged. Prokrastinasi, yang mungkin hanya didefinisikan sebagai penundaan tugas yang berulang, adalah salah satu masalah yang kebanyakan orang menderita dalam situasi tertentu.

Prokrastinasi adalah sebuah perilaku yang sangat rentan terjadi di kalangan remaja terutama kalangan pelajar. Perilaku ini bisa disebabkan oleh berbagai hal baik dari segi keadaan siswa atau keadaan lingkungannya. Lebih jelasnya prokrastinasi merupakan suatu perilaku tidak terkontrol yang dialami oleh seseorang dalam pekerjaan atau tugas-tugasnya, sehingga menjadikan pekerjaannya tersebut tertunda atau tidak selesai tepat pada waktu yang ditentukan. Perilaku prokrastinasi ini juga disebut sebagai indikasi kurangnya motivasi berprestasi. 
Bimbingan dan konseling adalah proses pemberian bantuan dari seorang konselor kepada konselinya untuk membantu konseli menyelesaikan dan mengatasi masalah yang sedang dihadapi.

Bimbingan dan Konseling adalah sebuah program yang bertujuan untuk membantu peserta didik dalam mengoptimalkan perkembangannya. Perkembangan yang dimaksudkan, baik dalam bidang akademik maupun perilaku yang dimiliki peserta didik tersebut. Dengan kata lain, guru Bimbingan dan Konseling bertugas membantu peserta didik dalam berbagai hal, baik secara tatap muka ataupun melalui berbagai media. Bantuan tersebut nantinya bisa membantu peserta didik dalam menyelesaikan masalah yang dimilikinya.

Dalam rangka meneyelesaikan masalah peserta didik, guru bimbingan dan konseling bisa menggunakan beberapa layanan yang sudah ada. Diantara beberapa layanan pemberian bantuan kepada peserta didik yaitu layanan konseling kelompok. Layanan konseling kelompok merupakan kegiatan pemberian bantuan dalam sebuah kelompok, dimana salah satu anggota yang memiliki masalah menceritakan masalahnya, dan anggota yang lain memberikan bantuan serta tanggapan untuk membantu menyelesaikan masalah yang dialami anggota tersebut.

Konseling kelompok menurut Corey adalah suatu layanan yang dapat mencegah atau memperbaiki baik pada bidang pribadi, sosial, belajar maupun karir(Corey, 2013a). Fokus penekanan yang dilakukan dalam konseling kelompok adalah komunikasi antar anggota yang tergabung dalam kelompok tersebut. Lebih jelasnya, konseling kelompok dilaksanakan untuk menyelesaikan masalah yang dihadapi oleh anggota kelompok tersebut.

Dalam praktiknya, komunikasi yang terjalin dalam sebuah kelompok, melibatkan pemikiran dan perasaan dalam pelaksanaannya. Mereka memiliki fokus dan tujuan yang mungkin sejalan dan setiap anggota kelompok bebas berpendapat. Setiap anggota kelompok bisa menjadi konselor bagi anggota kelompok yang lain. hal ini sangat membantu terbentuknya jiwa saling membantu dengan memperhatikan perbedaan karakteristik masingmasing anggota dan permasalahan yang dialami. Melalui dinamika kelompok yang dibangun dalam konseling kelompok ini, setiap anggota bisa mengembangkan potensi-potensi yang dimilikinya serta membantu permasalahan yang dialami oleh anggota lainnya.

Konseling kelompok memiliki beberapa tujuan, diantaranya dapat meningkatkan kesadaran setiap anggota dan dapat mengembangkan pencapaian pengetahuan. Dapat dijelaskan pula bahwa dengan adanya konseling kelompok, seseorang akan lebih peka dalam membantu orang lain. Mengembangkan sikap kedewasaannya dan menjadikan dirinya seorang yang lebih bijak dalam menghadapi sebuah masalah.

Tahapan Konseling Kelompok

Menurut Corey terdapat empat tahapan yang ada dalam proses layanan konseling kelompok, yakni inital stage, transition stage, working stage dan terminating stage. Penjelasan dari beberapa tahapan diatas yaitu sebagai berikut: 1) Inital Stage, dalam tahapan ini, setiap anggota dalam kelompok membangun suasana baik dalam sebuah kelompok dengan adanya perkenalan(Corey, 2013b). Perbincangan dengan membahas sebuah topik ringan dapat mencairkan suasana dan membuat setiap anggota lebih nyaman dengan anggota lainnya. Tahapan ini bertujuan pula memecahkan keheningan yang biasanya muncul ketika seseorang bertemu dengan orang-orang baru. Tahapan ini merupkan tahapan awal yang sangat berpengaruh dengan keberlanjutan tahap-tahap setelahnya. 2) Transition stage,pada tahapan ini, anggota kelompok akan belajar dan menguji apakah lingkungan yang sedang ia rasakan itu ada atau tidak untuknya mengekspresikan diri dan memaparkan permasalahan yang dimiliki. Beberapa anggota akan mulai mengamati apakah dirinya didengarkan, diterima dengan baik atau tidak, dan mulai membiasakan diri dengan beberapa keadaan yang ada 3) Working Stage, tahap ini adalah tahap dimana setiap anggota mulai memaparkan poin yang bisa disampaikan. Dalam tahap kerja ini tidak ada pembatas dengan tahap tahap lain. hanya 
saja tidak semua anggota kelompok bisa mencapai tahapan kerja ini dengan tingkatan yang sama. Ada yang berperan aktif, ada yang biasa saja dan bahkan mungkin ada pula yang pasif. Untuk itu tahapan ini tidak harus memberatkan setiap anggota berperan sama aktif dalam menanggapi sebuah pemecahan masalah 4) Tahap terminating, pada tahap ini anggota kelompok diajak untuk merasakan perasaan yang berkaitan dengan perpisahan, beberapa masalah yang mungkin belum menemukan pemecahan, penyampaian kesan pesan dan perasaan yang dialami ketika berada dalam sebuah dinamika kelompok, serta pengalaman dan pemberian umpan balik atas apa yang sudah dilaksanakan.

Terapi realita adalah salah satu bentuk psikoterapi yang mulai dikembangkan di era ini. Terapi ini dilandasi oleh kenyataan bahwa individu berhak memilih dan bertanggung jawab atas pilihannya(Glasser, 1965). Dalam pelaksanaannya, konselor berperan aktif dalam proses pemberian bantuan. Konselor berperan sebagai model dan sebagai guru bagi konseli. Dalam praktiknya pula, konseli dan konselor membuat beberapa kontrak dalam menyelesaikan masalah yang dihadapi untuk membantu mempermudah proses konseling yang dilaksanakan.

Dalam pelaksanaan konseling menggunakan terapi realita, ada beberapa karakter yang menjadi ciri dari proses pelaksanaannya, yaitu tidak terpaku pada masa lalu dan kejadiankejadian yang sudah terjadi sebelumnya. Namun konseli terfokus pada apa yang ia jalani saat ini. Hal ini dilakukan untuk mendorong konseli bisa terfokus menyelesaikan masalah yang dihadapinya sekarang, tanpa harus terpengaruh dengan kejadian masa lalunya yang bisa menghambat pengembangannya di masa sekarang.mudahnya, proses konseling ini lebih menekankan pada perubahan tingkah laku yang lebih bertanggung jawab dengan merencanakan dan melakukan tindakan-tindakan tersebut.

Tahapan Terapi Realita

Proses konseling dalam pendekatan realita berpedoman pada dua unsur utama, yaitu menjadi pedoman untuk mendorong terjadinya perubahan pada konseli. Secara praktis Thompson, et. Al. mengemukakan delapan tahapan konseling realita: 1) Konselor menunjukan keterlibatan dengan konseli (Be Friend), 2) Fokus pada perilaku sekarang, 3) Mengeksplorasi total behavior konseli, 4) Konseli menilai diri sendiri atau melakukan evaluasi, 5) Merencanakan tindakan yang bertanggung jawab, 6) Membuat komitmen, 7) Tidak menerima permintaan maaf atau alasan konseli, 8) Tindak lanjut(Gantina, Komalasari, \& Wahyuni, 2011).

Istilah prokrastinasi ini pertama kali dicetuskan oleh Brown \& Holtzman pada tahun 1967. Istiah ini berakar dari bahasa latin "procrastinare" yang berarti menunda sampai hari selanjutnya(Arumsari \& Muzaqi, 2016). Prokrastinasi akademik merupakan prokrastinasi yang berkaitan dengan unsur-unsur tugas dalam area akademik. Solomon \& Rothblim (1984) menyatakan terdapat enam area akademik yaitu tugas mengarang, belajar menghadapi ujian, membaca buku, menghadiri pertemuan dan kinerja akademik secara keseluruhan. Berdasarkan beberapa kajian literatur dikatakan bahwa ada dua faktor utama yang memengaruhi prokrastinasi yaitu faktor internal dan eksternal. Faktor internal faktor-faktor yang berasal dari individu yang turut membentuk perilaku prokrastinasi yang meliputi faktor fisik dan psikologis. Faktor eksternal yaitu faktor yang berasal dari luar individu dapat berupa tugas yang banyak yang menuntut penyelesaian yang hampir bersamaan (Rumiani, 2006).

\section{Metode Penelitian}

Penelitian ini menggunakan desain kuasi eksperimen. Dalam peneltian ini peneliti menggunakan desain penelitian dengan bentuk pretest-post-test (control grup design). Pada desain jenis penelitian ini terdiri dari satu kelompok eksperimen dan satu kelompok kontrol yang masing-masing terlebih dahulu diberikan pretest lalu diberikan perlakuan yang 
berbeda. Setelah diberi perlakuan, setiap kelompok langsung diberi posttest untuk mengetahui efek dari perlakuan tersebut.

Tabel 1. Desain Penelitian

\begin{tabular}{|c|c|c|c|}
\hline Kelompok & Pretest & Perlakuan & Post-tets \\
\hline Eksperimen & $\mathrm{O}_{1}$ & $\mathrm{X}_{1}$ & $\mathrm{O}_{2}$ \\
\hline Kontrol & $\mathrm{O}_{1}$ & $\mathrm{X}_{2}$ & $\mathrm{O}_{2}$ \\
\hline
\end{tabular}

Keterangan:

$\mathrm{X} 1$ : Pemberian perlakuan berupa konseling kelompok berdasarkan terapi realitas

X2 : Bentuk perlakuan hanya dibiarkan

$\mathrm{O}_{1}$ :Pretest (tingkat penundaan tugas sebelum diberikan perlakuan)

$\mathrm{O}_{2}$ :Post-test (tingkat penundaan tugas setelah diberikan perlakuan)

Hipotesis

Ho: tidak terdapat pengaruh

Ha : terdapat pengaruh

Konseling Kelompok berdasarkan terapi realitas dapat menurunkan Prokrastinasi (penundaan tugas) akademik siswa.

Penelitian dilaksanakan di MA Mafaza, Ketandan, Banguntapan, Bantul. Populasi dalam penelitian ini adalah siswa kelas X A dan B pada tahun ajaran 2017/2018 yang berjumlah 31 siswa. Cara pengambilan sampel dalam penelitian ini menggunakan purposive sampling. Purposive sampling merupakan teknik penarikan sampel yang didasarkan pada ciri atau karakteristik (tujuan) yang telah ditetapkan oleh peneliti sebelumnya. Sampel penelitian berjumlah 14 orang siswa yang dibagi menjadi dua kelompok, kelompok pertama merupakan kelompok eksperimen yakni sebanyak 7 siswa diberikan perlakuan berupa Konseling Kelompok berdasarkan terapi realita. Sedangkan kelompok kedua merupakan kelompok kontrol yang tidak mengikuti Konseling Kelompok berdasarkan terapi realita yakni sebanyak 7 siswa.

Pelaksanaan Konseling Kelompok berdasarkan terapi realita dalam penelitian ini adalah suatu bentuk kegiatan konseling yang diberikan kepada siswa untuk menurunkan tingkat prokrastinasi siswa. Pemberian Konseling Kelompok berdasarkan terapi realita ini dilakukan selama 1 minggu terdiri dari 5 sesi dengan durasi 60 menit tiap sesi.

Variabel penelitian pada dasarnya adalah segala sesuatu yang berbentuk apa saja yang ditetapkan oleh peneliti untuk dipelajari sehingga diperoleh informasi tentang hal tersebut, kemudian ditarik kesimpulannya. Variabel bebas adalah variabel yang mempengaruhi yang menjadi sebab adanya perubahan sedangkan variabel terikat adalah variabel yang dipengaruhi atau yang menjadi akibat(Sugiyono, 2010). Penelitian ini memiliki dua variabel yaitu;

a. Variabel independen (bebas) : Konseling Kelompok berdasarkan terapi realitas

b. Variabel dependen (terikat) : Prokrastinasi (penundaan tugas) akademik 
Operasional variabel merupakan penjabaran konsep variabel menjadi konsep yang sederhana yaitu indikator. Sehingga dapat menjadi rujukan dalam penyusunan instrumen penelitian. Adapun definisi operasional dalam penelitian ini dijabarkan sebagai berikut:

a. Konseling Kelompok berdasarkan terapi realitas

b. Prokrastinasi (penundaan tugas) akademik

Pengumpulan data merupakan salah satu serangkain langkah yang harus dilakukan dalam penelitian. Salah satu teknik pengumpulan data adalah dengan menggunakan kuesioner atau lebih dikenal sebagai angket. Angket adalah alat pengumpul data untuk kepentingan penelitian.

Dalam penelitian ini, peneliti mengumpulkan data dengan menggunakan kuesioner. Dalam hal ini, peneliti menggunakan skala prokrastinasi sebagai instrumen pengumpul data. Data yang diperoleh dari lapangan melalui instrumen penelitian selanjutnya diolah dan dianalisis, dengan maksud untuk menjawab pertanyaan penelitian dan menguji hipotesis penelitian tersebut diterima atau ditolak.

Dalam penelitian ini analisis data yang digunakan adalah Uji Wilxoccon yang merupakan metode statistika yang dipergunakan untuk menguji perbedaan 2 buah data yang berpasangan, maka jumlah sampe datanya selalu sama banyaknya(Walpole, 1995).

\section{Hasil dan Pembahasan}

Prokrastinasi akademik dalam penelitian ini diukur dengan menggunakan skala prokrastinasi akademik. Semakin tinggi skor total yang diperoleh, maka menunjukkan semakin tinggi prokrastinasi akademik subjek. Demikian pula sebaliknya, semakin rendah skor total yang diperoleh subjek menunjukkan semakin rendah prokrastinasi akademik subjek.

Secara umum, tingkat prokrastinasi tingkat akademik siswa kelas X A dan B MA Mafaza baik pada kelompok eksperimen maupun kelompok kontrol berada pada kategori tinggi dengan prosentasi sebesar 45, $16 \%$.

Tabel 2. Hasil Uji Wilxocon Skor Pre-test dan Pos-test Tingkat Prokrastinasi Akademik Kelompok Eksperimen.

\begin{tabular}{|ll|r|r|r|}
\hline & $\mathrm{N}$ & $\begin{array}{r}\text { Mean } \\
\text { Rank }\end{array}$ & $\begin{array}{c}\text { Sum of } \\
\text { Ranks }\end{array}$ \\
\hline $\begin{array}{llr}\text { Post Test }- \\
\text { Pre Test }\end{array}$ & $\begin{array}{l}\text { Negative } \\
\text { Ranks } \\
\text { Positive } \\
\text { Ranks } \\
\text { Ties }\end{array}$ & $6^{\mathrm{a}}$ & 3.50 & 21.00 \\
& $0^{\mathrm{b}}$ & .00 & .00 \\
& & & \\
\hline Total & 7 & & \\
\hline
\end{tabular}

a. Post Test $<$ Pre Test

b. Post Test $>$ Pre Test

c. Post Test $=$ Pre

Test 
Berdasarkan tabel 1 terdapat 6 sampel yang tingkat prokrastinasi akademiknya lebih kecil setelah diberi perlakuan dibandingkan sebelumnya. Artinya ada 6 sampel yang mengalami penurunan tingkat prokrastinasi setelah diberikan Bimbingan Konseling Kelompok menggunakan terapi realita. Pada kolom positive ranks menunjukkan bahwa tidak ada sampel yang tingkat kecemasannya meningkat setelah diberi diberikan Bimbingan Konseling Kelompok menggunakan terapi realita. Sedangkan pada kolom Ties terdapat 1 sample yang menunjukkan bahwa tidak terjadi perubahan atau penurunan apapun setelah diberi diberikan Bimbingan Konseling Kelompok menggunakan terapi realita

\section{Test Statistics $^{b}$}

\begin{tabular}{|l|r|}
\hline & $\begin{array}{r}\text { VAR00002 - } \\
\text { VAR00001 }\end{array}$ \\
\hline$Z$ & $-2.207^{\mathrm{a}}$ \\
$\begin{array}{l}\text { Asymp. Sig. (2- } \\
\text { tailed) }\end{array}$ & .027 \\
\hline
\end{tabular}

a. Based on positive ranks.

b. Wilcoxon Signed Ranks Test

Hasil output diatas menunjukkan bahwa nilai $\mathrm{P}$ atau $\mathrm{Pv}$ sebesar 0,027 . Sedangkan taraf signifikan $(\alpha)$ penelitian sebesar 0,05 . Sehingga nilai $\mathrm{P}<\alpha$ atau $0.027<0,05$ maka Ho ditolak, artinya terdapat pengaruh pemberian Konseling Kelompok menggunakan Terapi realita terhadap penurunan tingkan prokrastinasi akademik siswa.

Setelah mengetahui bahwa terdapat pengaruh dari perlakuan yang diberikan, maka uji selanjutnya untuk menentukan apakah terdapat perbedaan pengaruh antara kelas eksperimen dan kelas kontrol menggunakan uji Mann Whitney $U$.

Tabel 2. Hasil Uji Mann-Whitney Scor Gain Pre-test dan Post-Test Tingkat Prokrastinasi Akademin Siswa Kelompok Eksperimen dan Kelompok Kontrol

\section{Ranks}

\begin{tabular}{|c|r|r|r|}
\hline $\begin{array}{l}\text { Kel } \\
\text { omp } \\
\text { ok }\end{array}$ & N & $\begin{array}{c}\text { Mean } \\
\text { Rank }\end{array}$ & $\begin{array}{c}\text { Sum of } \\
\text { Ranks }\end{array}$ \\
\hline scor 1 & 7 & 4.93 & 34.50 \\
2 & 7 & 10.07 & 70.50 \\
Tot \\
al
\end{tabular}


Test Statistics ${ }^{b}$

\begin{tabular}{|l|r|}
\hline & \multicolumn{1}{|c|}{ Scor } \\
\hline Mann-Whitney U & 6.500 \\
Wilcoxon W & 34.500 \\
Z & -2.310 \\
Asymp. Sig. (2-tailed) & .021 \\
Exact Sig. [2*(1-tailed & $.017^{\mathrm{a}}$ \\
Sig.)] & \\
\hline
\end{tabular}

Tabel di atas menunjukkan nilai U sebesar 6,5 dan nilai $\mathrm{W}$ sebesar 34,5. Apabila dikonversikan ke nilai Z maka besarnya -2.310. Nilai Sig atau P Value sebesar 0,021 > 0,05 . Nilai $\mathrm{p}$ value $>$ taraf signifikan 0.05 maka tidak terdapat perbedaan yang bermakna antara kelompok eksperimen dan kelompok kontrol.

\section{Simpulan dan Saran}

Berdasarkan hasil analisis dan pembahasan yang telah dipaparkan, maka dapat disimpulkan bahwa terdapat pengaruh antara pemberian konseling kelompok berdasarkan terapi realita terhadap tingkat prokrastinasi akademik siswa. Artinya tingkat prokrastinasi akademik siswa pada kelompok eksperimen yang diberikan perlakuan konseling kelompok berdasarkan terapi realita mengalami penurunan apabila dibandingkan dengan kelompok kontrol yang tidak diberikan perlakuan.

Hasil penelitian ini menyatakan bahwa konseling kelompok berdasarkan terapi realita efektif menurunkan tingkat prokrastinasi akademik siswa, oleh karena itu diharapkan para pendidik dapat menerapkan pendekatan ini sebagai alternatif pemecahan masalah prokrastinasi akademik. Disarankan kepada para akademisi dan peneliti selanjutnya yang akan mengungkap masalah prokrastinasi akademik hendaknya menggunakan pendekatan yang menyangkut terapi realita baik secara individu maupun kelompok. Sehingga dapat menambah alternatif pemecahan masalah yang berkaitan dengan prokrastinasi akademik.

\section{Daftar Pustaka}

Arumsari, A. D., \& Muzaqi, S. (2016). Prokrastinasi Akademik pada Mahasiswa yang Bekerja. E-Jurnal SPIRIT PRO PATRIA, 2(2), 30-39. Retrieved from http://jurnal.narotama.ac.id/index.php/patria/article/view/534

Corey, G. (2013a). Teori dan Praktek. Konseling dan Psikoterapi. Bandung: Refika Aditama. Corey, G. (2013b). Theory and practice of counseling and psychotherapy. Theory and Practice of Counseling and Psychotherapy 5th Ed. https://doi.org/10.1016/00223999(94)90123-6

Gantina, Komalasari, \& Wahyuni, E. (2011). Teori Teknik Konseling. Jakarta: Indeks.Gunarsa.

Glasser, W. (1965). A New Approach to Psychiatry. Harper and Row, Pub., New York.

Rumiani, R. (2006). Prokrastinasi Akademik Ditinjau dari Motivasi Berprestasi dan Stres Mahasiswa. Jurnal Psikologi Undip, 3(2).

Sugiyono. (2010). Metode Penelitian Pendidikan Pendekatan Kuantitatif, Kualitatif, dan $R \& D$. bandung: $C V$.alfabeta.

Walpole, R. E. (1995). Pengantar Statistika edisi ke-3. Jakarta: Gramedia Pustaka Utama. 
